\title{
CD Interkatif Sebagai Media Pembelajaran
}

\author{
Dede Vera Vardian ${ }^{1}$, Heni Wulandari ${ }^{2}$, Arif Yudianto ${ }^{3}$ \\ Pendidikan Teknologi Informasi dan Pendidikan Teknologi Informasi, Universitas Muhammadiyah Sukabumi \\ JL.R Syamsudin, S.H. No 50, Cikole, Kec.Cikole, Kota Sukabumi, Jawa Barat \\ dedeveravardian06egmail.com \\ heni.mpaegmail.com \\ arif.yudianto01@ummi.ac.id
}

\begin{abstract}
Abstact - This research aims to develop an interactive CD learning media as an interesting learning media for class $\mathrm{X}$ in Physical Education, Sports and Health (PJOK).This study also aims to determine the feasibility of an Interactive CD learning media. This research is a development research using Borg and Gall development models, namely (1) Potential and Problems, (2) Data Collection, (3) Product Design, (4) Design Validation, (5) Design Revision, (6) Product Trial, (7) Product Revision, (8) Usage / Field Trial, (9) Product Revision, and (10) Mass Production. The results of the feasibility study of the Interactive Learning Media CD with an average score given by: (1) Material Expert that is 4.3 in the category Very Feasible, (2) Design Expert that is 4.3 in the category Very Feasible, (3) Expert The media are 3.5 with the Eligible category, (4) Limited Class Trial by 6 students, 4 with the Eligible category and (5) Field Trial by 20 students, 4.6 with the Very Eligible category.
\end{abstract}

\section{Keywords - Learning Media, Interactive CD}

\begin{abstract}
Abstrak - Penelitian ini bertujuan mengembangkan media pembelajaran CD Interkatif sebagai media pembelajaran yang menarik kelas $X$ di pelajaran Pendidikan Jasmani, Olahrga, dan Kesehatan (PJOK). Penelitian ini juga bertujuan untuk mengetahui kelayakan media pembelajaran CD Interkatif. Penelitian ini merupakan penelitian pengembangan yang menggunakan model pengembangan Borg dan Gall yaitu (1) Potensi dan Masalah, (2) Pengumpulan Data, (3) Desain Produk, (4) Validasi Desain, (5) Revisi Desain, (6) Uji Coba Produk, (7) Revisi Produk, (8) Uji Coba Pemakaian / Lapangan, (9) Revisi Produk, dan (10) Produksi Masal. Hasil penelitian uji kelayakan Media Pembelajaran CD Interkatif dengan skor rata-rata yang di diberikan oleh: (1) Ahli Materi yaitu 4,3 dengan kategori Sangat Layak, (2) Ahli Desain yaitu 4,3 dengan kategori Sangat Layak, (3) Ahli Media yaitu 3,5 dengan kategori Layak, (4) Uji Coba Kelas Terbatas oleh 6 siswa yaitu 4 dengan kategori Layak dan (5) Uji Coba Lapangan oleh 20 siswa yaitu 4,6 dengan kategori Sangat Layak.
\end{abstract}

Kata Kunci - Media Pembelajaran, CD Intektif

\section{PENDAHULUAN}

Pendidikan merupakan sejumlah pengalaman dari seseorang atau kelompok untuk dapat memahami sesuatu yang sebelumnya tidak mereka pahami. Pengalaman itu terjadi karena adanya interaksi antara seseorang atau kelompok dengan lingkungannya. Interaksi itu menimbulkan proses perubahan (belajar) pada manusia dan selanjutnya proses perubahan itu menghasilkan perkembangan (development) bagi kehidupan seseorang atau kelompok dalam lingkungan [1]

Ambarjaya (2012:5) pendidikan terbagi menjadi 3 jenis, yaitu pendidikan informal, pendidikan formal, dan pendidikan non formal [1].

Pendidikan formal ada beberapa jenis di antaranya TK, SMP, SMA, Universitas/ Perguruan Tinggi dan Sekolah
Menengah Kejuruan (SMK) merupakan sekolah pendidikan formal selain SMA/MA/MAK sederajat. Di SMK banyak sekali mata pelajaran yang berhubungan dengan praktek terutama pelajaran produktif, karena lulusan SMK di bentuk untuk siap bekerja sesuai dengan keahlian tertentu sesuai dengan bakat dan minat para siswa. Hal ini sesuai dengan pernyataan Peraturan Pemerintah No.29 Tahun 1990 tentang Pendidikan Menengah Bab I Ayat 1 Pasal 3, bahwa "Pendidikan Menengah Kejuruan adalah pendidikan pada jenjang menengah yang mengutamakan pengembangan kemampuan siswa untuk melaksanakan jenis pekerjaan tertentu" [2].

Sekolah Menengah Kejuruan (SMK) Selain memiliki keahlian tertentu siswa SMK juga di tuntut untuk memiliki fisik yang sehat dan kuat, tidak jarang ketika penerimaan 
siswa baru di SMK di adakan berbagai macam tes sebelum meloloskan para peserta didik baru sesuai standar yang di tentukan di sekolah masing-masing, tes yang di adakan ada beberapa macam diantaranya adalah tes fisik, tes kesehatan, tes akademik, tes kompetensi keahlian. Hal ini mengacu karena banyaknya kalangan dunia industri yang menerapkan persyaratan ketat dalam penerimaan lulusan SMK pada dunia kerja. Sehingga SMK lebih menyeleksi siswa pilihan untuk nantinya di bekali kembali berbagai macam wawasan pengetahuan, pengembangan kemampuan, pelatihan mental dan fisiknya.

Mata pelajaran Pendidikan Jasmani, Olahraga dan Kesehatan (PJOK) di SMK sangatlah penting untuk membentuk fisik yang sehat dan kuat para siswanya, pendidikan jasmani merupakan pendidikan yang tidak bisa dipisahkan dengan pendidikan nasional yang bertujuan untuk pengembangkan kemampuan peserta didik.

Perencanaan pendidikan jasmani dilakukan secara seksama untuk memenuhi perkembangan, pertumbuhan, dan kebutuhan perilaku setiap anak. Maka pendidikan jasmani bukan hanya ditujukan untuk mengembangkan kemampuan psikomotorik, akan tetapi juga mengembangkan kemampuan kognitif dan afektif peserta didik [3]

Kemajuan ilmu pengetahuan dan kompleksnya tingkat berpikir siswa dalam pendidikan di Indonesia, dengan kemajuan tersebut sehingga menuntut guru atau pendidik untuk lebih memperhatikan hal ini. Karena guru merupakan faktor yang sangat dominan dan paling penting dalam pendidikan. Selain itu dalam proses belajar mengajar guru juga harus memiliki kemampuan tersendiri, guna mencapai harapan yang dicita-citakan dalam melaksanakan pendidikan pada umumnya dan proses belajar mengajar pada khususnya.

Hal yang bisa dilakukan guru dalam usaha untuk meningkatkan mutu pendidikan, diantaranya yaitu harus menggunakan media sebagai sarana pendukung proses belajar mengajar. Karena media merupakan suatu alat yang bisa membantu dalam kegiatan proses belajar mengajar. Media merupakan salah satu komponen komunikasi, yaitu sebagai pembawa pesan dari komunikator menuju komunikan. Criticos [4]. Dengan di bantu media pembelajaran CD Interaktif diharapkan dapat meningkatkan hasil belajar siswa, membangkitkan keinginan dan minat baru, membangkitkan motivasi rangsangan kegiatan belajar, membantu keefektifan penyampaian pesan, meningkatkan pemahaman, menyajikan data dengan menarik dan terpercaya, memudahkan penafsiran, serta memadatkan informasi. Guru tidak lagi dominan di dalam kelas, melainkan siswa yang menjadi subjek belajar.

Setelah melakukan penelitian di SMKN 1 Sukalarang ternyata mata pelajaran Pendidikan Jasmani, Olahraga dan Kesehatan (PJOK) terkadang tidak berjalan bagaimana mestinya masih banyak guru yang hanya mengandalkan buku paket atau LKS untuk keberlangsungan pembelajaran yang artinya terkadang hanya sekedar pembahasan materi dan gambar-gambar terbatas di buku tanpa adanya peraktek di lapangan, di mata pelajaran ini juga minimnya media pembelajaran yang beragam untuk menunjang materi tersebut sehingga peneliti memilih mata pelajaran Pendidikan Jasmani, Olahraga dan Kesehatan (PJOK) untuk di buatkan media pembelajarannya dengan tujuan supaya peserta didik dan guru bisa terangsang setelah melihat tayangan dan materi di media pembelajaran yang peneliti buat langsung memperaktekan langsung materi ini dengan bekal pengetahuan yang cukup dan teknik-teknik dasar yang akurat.

Setelah observasi awal yang dilakukan peneliti melalui wawancara dengan guru mata pelajaran Pendidikan Jasmani, Olahraga dan Kesehatan (PJOK) di SMK N 1 Sukalarang yaitu bapa Yoga Maulidi, S.Pd. Beliau mengungkapkan berbagai permasalahan sekolah menengah kejuruan salah satunya yaitu tentang Pendidikan Jasmani, Olahraga dan Kesehatan (PJOK) merupakan mata pelajaran dengan banyak praktek dan aktivitas di lapangan, tetapi seringkali berhalangan beraktivitas misalkan ketika cuaca sedang tidak mendukung proses pembelajaran di luar ruangan, kurangnya sarana prasarana untuk praktek, guru sedang berhalangan hadir dan tidak bisa mengajar di mata pelajaran ini, pembelajaran yang kurang menarik perhatian siswa karena tidak beragamnya media pembelajaran. Oleh karena itu peneliti menyimpulkan untuk mengembangkan sebuah media pembelajaran agar pembelajaran dapat disampaikan dengan menarik dan bisa mengatasi semua kendala yang ada.

Pendidikan Jasmani dan Kesehatan merupakan mata pelajaran yang ada di kelas X, XI, XII, dan yang akan di teliti merupakan kelas X di SMK N 1 Sukalarang. Media pembelajaran yang akan peneliti kembangkan adalah menggunakan CD Interkatif agar memudahkan guru dalam menyampaikan pembelajaran Pendidikan Jasmani Olahraga, dan Kesehatan (PJOK). Media CD Pembelajaran Interaktif dapat digunakan sebagai salah satu alternatif untuk menyampaikan pesan oleh pemberi pesan (guru) kepada penerima (siswa). Penggunaan media CD Pembelajaran Interaktif memungkinkan siswa tidak hanya belajar di sekolah saja, tetapi juga bisa belajar sendiri di rumah. CD interaktif merupakan bentuk dari bahan ajar interkatif yaitu "kombinasi dari dua atau lebih media (audio, teks, grafis, gambar, animasi, dan video) yang oleh penggunanya dimanipulasi untuk mengendalikan perintah atau perilaku alami dari suatu presentasi" [5]

Dari analisis yang peneliti lakukan maka peneliti mengangkat materi senam lantai di SMK N 1 Sukalarang kelas X maka peneliti menyimpulkan bahwa materi tersebut memerlukan tutor atau pelatih untuk membimbing berjalannya kegiatan ini tetapi kendala di SMKN 1 Sukalarang materi senam lantai jarang sekali di peraktekan karena guru olahraga yang jarang mempraktekan gerakan senam lantai, karena lebih sering di sana lebih mempraktekan jenis olahraga lain yang lebih umum seperti bola basket, bola volli, footsal dll, dan terkadang juga guru 
yang berhalang hadir untuk mengajar sehingga KBM (Kegiatan Belajar Mengajar) tidak efektif. Senam lantai hanya di bahas oleh guru materinya saja lewat buku paket atau LKS dengan gambar-gambar yang sederhana tanpa siswa bisa memahami lebih jelas tentang materi ini ,materi senam lantai biasanya menggunakan minimal menampilkan video, dan suara untuk memeragakan semua gerakan tersebut dengan baik ketika tidak ada seorang instruktur yang memandu, di dalam CD Interaktif semua yang di perlukan ada. Selain itu materi ini sangat cocok jika di sandingkan dengan media pembelajaran CD Interaktif, karena CD Interaktif di dalamnya mengandung unsur video, suara, materi, serta quiz yang bisa di ikuti oleh siswa.

Penelitian dilakukan oleh Haniga Ardiatama (2015) tentang Pengembangan Multimedia Pembelajaran Interaktif (MPI) Materi Permainan Bola Voli Untuk Kelas 5 Di SD Tlogorejo 3 Demak. Berdasarkan hasil penilaian dari hasil rata-rata semaua aspek yang dinilai ahli materi memberikan skor sebesar $91.1 \%$, dan ahli media 1 sebesar $84 \%$ sedangkan ahli media 2 sebesar $87 \%$. sehingga dapat disimpulkan dapat disimpulkan bahwa media pembelajaran ini efektif digunakan dalam meningkatkan hasil belajar siswa.

Media pembelajaran menggunakan CD Interaktif bertujuan sebagai stimulus positif bagi siswa untuk menumbuhkan kreativitas, media yang menarik, inovatif dan relevan dengan perkembangan industri, membantu siswa dalam menerima materi dengan mudah dan cepat, juga merupakan media yang efektif karena dapat digunakan berulang-ulang setiap tahunnya pada mata pelajaran Pendidikan Jasmani dan Kesehatan (PJOK) dengan materi yang sama.

\section{METODOLOGI PENELITIAN}

Penelitian ini menggunakan metode penelitian dan pengembangan Research and Development yang mengacu pada model pengembangan Borg and Gall. Metode penelitian dan pengembangan atau dalam bahasa inggrisnya Research and Development adalah metode penelitian yang digunakan untuk menghasilkan produk tertentu, dan menguji keefektifan produk tersebut [6]

Langkah-langkah penggunaan Metode Research and Development

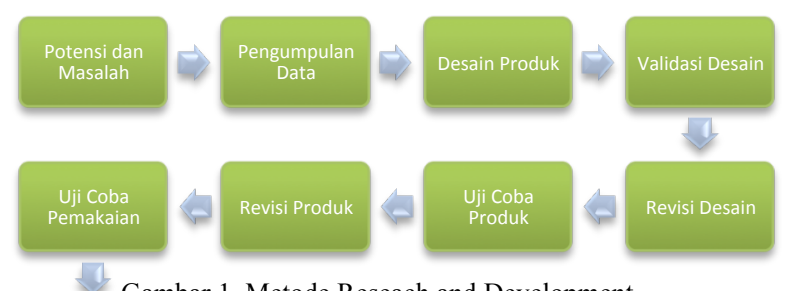

Gambar 1. Metode Reseach and Development

A. Potensi Dan Masalah

Potensi dan Másălah penelitian ini sesuai dengan hasil observasi awal melalui wawancara dengan guru mata pelajaran Pendidikan Jasmani, Olahraga, dan
Kesehatan (PJOK) SMK N 1 Sukalarang yaitu Bapa Yoga Maulidi, S.Pd sebagai berikut: 1) kurangnya sarana prasarana untuk praktek, 2) jarangnya guru yang mempraktekan gerakan senam lantai, 3) kurangnya minat siswa untuk belajar senam lantai.

Kemudian peneliti menanyakan lebih jauh tentang poin ke tiga yaitu kurangnya minat siswa untuk belajar senam lantai terutama pada mata pelajaran Pendidikan Jasmani, Olahraga, dan Kesehatan (PJOK). Setelah di observasi kembali ke guru mata pelajaran Pendidikan Jasmani, Olahraga, dan Kesehatan (PJOK) ternyata memang benar metode atau pendekatan pembelajaran yang kurang bisa membuat para siswa siswi bersemangat untuk mengikuti pembelajaran karena pada dasarnya mata pelajaran Pendidikan Jasmani, Olahraga, dan Kesehatan (PJOK) merupakan pembelajaran melalui aktivitas jasmani yang bertujuan untuk meningkatkan kebugaran jasmani, mengembangkan keterampilan motorik, pengetahuan dan perilaku hidup sehat dan aktif, sikap sportif, dan kecerdasan emosi.

\section{B. Pengumpulan Data}

Tahap selanjutnya yaitu mengumpulkan berbagai informasi yang dapat digunakan sebagai bahan untuk perencanaan pembuatan produk. Data yang di kumpulkan berupa silabus mata pelajaran Pendidikan Jasmani, Olahraga, dan Kesehatan (PJOK), buku paket Pendidikan Jasmani, Olahraga dan Kesehatan, tutorial pembuatan video pembelajaran dan CD Interaktif yang baik.

\section{Desain Produk}

Desain produk pada penelitian ini yaitu storyboard $C D$ Interaktif. Peneliti membuat rancangan sebagai rujukan mengembangankan $C D$ Interaktif yang akan dibuat. Storyboard akan menunjukan gambaran secara umum dan aliran setiap kemungkinan aktifitas dalam Media pembelajaran $C D$ Interaktif.

Desain produk berbentuk sebuah storyboard CD Interaktif dengan materi Senam lantai yang terdapat pada buku paket Pendidikan Jasmani, Olahraga, dan Kesehatan (PJOK)yang menjadi bahan ajar pada mata pelajaran Pendidikan Jasmani, Olahraga, dan Kesehatan (PJOK)di SMK N 1 Sukalarang.

\section{Validasi Ahli}

Langkah selanjutnya peneliti melakukan penelitian untuk memvalidasi media yang telah dibuat, layak dan tidaknya produk dinilai oleh ahli. Ahli media bertugas untuk memvalidasi media yang akan di gunakan apakah sudah layak dan tepat untuk sasaran yang dituju, ahli materi bertugas untuk memvalidasi apakah materi yang di sampaikan di dalamnya sudah sesuai dan cocok untuk tingkat yang akan menjadi sasaran. 


\section{E. Revisi Desain}

Proses validasi oleh ahli dapat mengetahui kekurangan atau kelemahan produk tersebut. Selanjutnya peneliti memperbaiki desain produk sesuai kekurangan/kelemahannya yang telah diketahui dari hasil validasi.

\section{F. Uji Coba Produk}

Uji coba produk dilakukan dengan uji coba kepada kelas X MULTIMEDIA 1.

\section{G. Revisi Produk}

Revisi dilakukan setelah uji coba tahap awal produk sebelum dilakukannya uji coba pemakaian.

\section{H. Uji Coba Pemakaian}

Uji coba dilakukan setelah mendapat validasi ahli dan tahap revisi desain. Produk dimplementasikan ke dalam pembelajaran Pendidikan Jasmani, Olahraga, dan Kesehatan (PJOK) di kelas $\mathrm{X}$ MULTIMEDIA 1 kemudian peran siswa menilai dan memberikan saran terhadap produk media pembelajaran CD Interaktif yang telah dikembangkan melalui angket.

Uji coba produk dilakukan dengan dua tahap, yaitu uji coba kelompok kecil dan uji coba lapangan.

1. Uji coba kelas terbatas

Tahap uji pegembangan awal dilakukan melalui uji coba terbatas di kelas X Multimedia 2 SMK Negeri 1 Sukalarang dengan jumlah 6 siswa secara random (acak). Hasil dari uji coba awal ini digunakan untuk melaksanakan tahap perbaikan desain revisi selanjutnya dari media video pembelajaran CD Interaktif. Hasil dari perbaikan desain revisi digunakan untuk uji coba lapangan.

2. Uji coba lapangan

Tahap ini merupakan tahap akhir dari pengembangan dimana produk jadi siap untuk diterapkan sebagai media pembelajaran Pendidikan Jasmani, Olahraga, dan Kesehatan (PJOK) pada siswa SMK. Uji coba lapangan dilaksanakan di kelas $\mathrm{X}$ Multimedia 1 dengan jumlah 20 siswa. Uji lapangan menghasilkan produk penelitian berupa media pembelajaran CD Interaktif.

\section{Revisi Produk}

Kekurangan akan kembali diperbaiki oleh peneliti sehingga dihasilkan produk yang lebih baik lagi.

\section{J. Produksi Masal}

Hasil akhir setelah dilakukan validasi, uji coba tahap awal, perbaikan, uji coba pemakaian, dan revisi hal yang dilakukan selanjutnya media pembelajaran dapat dipublikasikan.

Dari beberapa langkah penelitian dan pengembangan yang dilakukan maka dapat disimpulkan bahwa peneliti akan menggunakan metode penelitian dan pengembangan hingga tahap ke9 yaitu revisi produk dikarenakan keterbatasan waktu dan biaya.

\section{METODE PENGUMPULAN DATA}

Penelitian dan pengembangan ini menggunakan beberapa macam metode dalam mengumpulkan data, yaitu kuesioner, observasi, dan wawancara. Berikut penjelasan masing-masing metode.

\section{A. Wawancara}

Metode wawancara digunakan sebagai teknik pengumpulan data apabila peneliti ingin melakukan studi pendahuluan untuk menemukan permasalahn yang harus diteliti, dan juga apabila peneliti ingin mengetahui halhal dari responden yang lebih mendalam dan jumlah respondennya sedikit/kecil [6]

Metode wawancara dipilih karena peneliti dapat lebih dekat dengan narasumber sehingga informasi yang diperoleh lebih mendalam. Wawancara dilakukan dengan guru mata pelajaran Pendidikan Jasmani, Olahraga, dan Kesehatan (PJOK) mengenai permasalahan pembelajaran di SMK N 1 Sukalarang dan para siswa di sana.

\section{B. Kuesioner (Angket)}

Kuesioner merupakan teknik pengumpulan data yang dilakukan dengan cara memberi seperangkat pertanyaan atau pertanyaan tertulis kepada responden untuk dijawabnya. Kuesioner merupakan teknik pengumpulan data yang efisien bila peneliti tahu dengan pasti variabel yang akan diukur dan tahu apa yang bisa diharapkan dari responden [6].

Metode Kuesioner dipilih karena peneliti dapat lebih banyak mengumpulkan data dan informasi dengan waktu yang sama untuk di teliti. Kuesioner dilakukan dengan guru mata pelajaran Pendidikan Jasmani, Olahraga, dan Kesehatan (PJOK) mengenai permasalahan pembelajaran di SMK N 1 Sukalarang dan para siswa di sana.

\section{Observasi}

Observasi sebagai teknik pengumpulan data mempunyai ciri yang spesifik bila dibandingkan dengan teknik yang lain, yaitu wawancara dan kuesioner. Kalau wawancara dan kuesioner selalu berkomunikasi dengan orang, maka observasi tidak terbatas pada orang, tetapi juga obyek-obyek alam yang lain [6].

Metode observasi dipilih karena peneliti dapat lebih banyak melihat langsung tanpa terbatas oleh sesuatu tentang permasalahan yang ada Observasi dilakukan dengan guru mata pelajaran Pendidikan Jasmani, Olahraga, dan Kesehatan (PJOK)mengenai 
permasalahan pembelajaran di SMK N 1 Sukalarang dan para siswa di sana.

\section{HASIL PENELITIAN DAN PEMBAHASAN}

Berdasarkan hasil penelitian yang di lakukan di SMK N 1 sukalarang melalui penerapan CD Interaktif pada mata pelajaran Pendidikan Jasmani, Olahraga, dan Kesehatan (PJOK) menghasilkan beberapa penilaian dari para ahli dan juga siswa tentang kelayakan penggunaan media pembelajaran ini.

\section{A. Validasi Ahli Materi}

Validasi ini bertujuan untuk menilai kesesuaian desain produk dengan kebutuhan media pembelajaran. Validasi ini dilakukan oleh ahli materi yaitu Yoga Maulidi, S.Pd yang merupakan guru Pendidikan Jasmani, Olahraga dan Kesehatan (PJOK) di SMK N 1 Sukalarang.

Proses penilaian oleh ahli materi terhadap rancangan produk. Penilaian materi pembelajaran oleh ahli materi memiliki 15 aspek yang dinilai dari (1) Kesesuaian materi dengan Kompetensi Inti (KI) dan Kompetensi Dasar (KD), (2) Kebenaran konsep, (3) Kemuktahiran materi, (4) Urutan penyajian materi, (5) Kesesuaian contoh yang di berikan, (6) Tujuan pembelajaran, (7) Rangkuman, (8) Kejelasan indikator pembelajaran, (9) Kesesuaian gambar, (10) Video yang diberikan untuk memperjelas materi, (11) Kesesuaian bahasa dengan tingkat berfikir siswa, (12) Kelugasan bahasa, (13) Ketepatan istilah, (14) Ketepatan tata bahasa dan ejaan dan, (15) Kemampuan membangkitkan rasa ingin tahu siswa. Keseluruhan skor pada 15 aspek yang dinilai oleh ahli materi revisi I memperoleh nilai 4,2 atau $84 \%$ dengan kategori "Layak". Hasil penilaian dari revisi II nilai yaitu 4,4 atau 89\% dengan kategori "Sangat Layak". Sehingga mendapatkan rata-rata dari hasil penilaian ahli materi yaitu 4,3 atau $86 \%$ yaitu dengan kriteria kelayakan "Sangat layak" untuk di ujicobakan. Berikut tabel hasil penilaian dari ahli materi.

\section{B. Validasi Ahli Desain}

Validasi ini bertujuan untuk menilai kesesuaian desain produk dengan kebutuhan media pembelajaran. Validasi ini dilakukan oleh ahli desain yaitu Dede, M.Kom yang merupakan guru program studi multimedia di SMK N 1 Sukalarang.

Proses penilaian oleh ahli desain terhadap rancangan produk. Penilaian desain pembelajaran oleh ahli desain memiliki 8 aspek yang dinilai dari (1) Keselarasan / irama, (2) Kesatuan (unity), (3) penekanan (emphasis), (4) Kesimbangan (Balance), (5) Kesebandingan (propotion), (6) Kesederhanaan (simplicity), (7) Kejelasan dan (8) Kesesuaian desain untuk karakteristik peserta didik SMK. Keseluruhan skor pada 8 aspek yang dinilai oleh ahli desain revisi I memperoleh nilai 4,1 atau $82 \%$ dengan kategori "Layak". Hasil penilaian dari revisi II nilai yaitu 4,5 atau $90 \%$ dengan kategori "Sangat Layak". Sehingga mendapatkan rata-rata dari hasil penilaian ahli materi yaitu 4,3 atau $86 \%$ yaitu dengan kriteria kelayakan "Sangat layak" untuk di ujicobakan. Berikut tabel hasil penilaian dari ahli desain.

\section{Validasi Ahli Media}

Validasi ini bertujuan untuk menilai kesesuaian desain produk dengan kebutuhan media pembelajaran. Validasi ini dilakukan oleh ahli media yaitu Luthpi Saepuloh, M.Pd yang merupakan seorang dosen program studi Pendidikan Teknologi Informasi Universitas Muhammadiyah Sukabumi.

Proses penilaian oleh ahli media terhadap rancangan produk. Penilaian media pembelajaran oleh ahli media memiliki 8 aspek yang dinilai dari (1) Menu sajian, (2) Huruf, (3) Keterbacaan teks, (4) Video, (5) Gambar, (6) Tata letak, (7) Warna background, (8) Kesesuaian desain untuk karakteristik peserta didik SMK. Keseluruhan skor pada 8 aspek yang dinilai oleh ahli media revisi I memperoleh nilai 3,1 atau $62 \%$ dengan kategori "Cukup". Hasil penilaian dari revisi II nilai yaitu 3,8 atau $77 \%$ dengan kategori "Layak". Sehingga mendapatkan rata-rata dari hasil penilaian ahli materi yaitu 3,5 atau $70 \%$ yaitu dengan kriteria kelayakan "Layak" untuk di ujicobakan. Berikut tabel hasil penilaian dari ahli media.

\section{Uji Coba Pemakaian}

\section{Uji Coba Kelas Terbatas}

Uji coba kelompok kecil ini dilakukan oleh 6 siswa X Multimedia 1 SMK N 1 Sukalarang. Media yang terlebih dahulu telah divalidasi dan di revisi sesuai dengan saran ahli materi, ahli desain dan ahli media kemudian dilakukan uji pengembangan. Uji pengembangan dilaksanakan melalui uji terbatas dengan tujuan untuk mengetahui kelayakan dari media (produk) yang di hasilkan dalam proses pembelajaran Pendidikan Jasmani Olahraga, dan Kesehatan (PJOK) agar sesuai dengan rencana pengajaran sehingga pada akhirnya media benar-benar siap untuk uji coba lapangan pada siswa X Multimedia 2 SMK N 1 Sukalarang. Hasil dari uji coba pengembangan ini akan dijadikan pedomana revisi sebelum uji coba lapangan dilaksanakan.

Dapat disimpulkan bahwa aspek penilaian media dinyatakan "Layak" digunakan sebagai media pembelajaran Pendidikan Jasmani Olahraga, dan Kesehatan (PJOK) di SMK N 1 Sukalarang yaitu aspek pemakaian diperoleh hasil 4 atau $81 \%$.

\section{Uji Coba Lapangan}


Uji coba kelompok besar ini dilakukan oleh 20 siswa X Multimedia 2 SMK N 1 Sukalarang. Media yang terlebih dahulu telah divalidasi dan direvisi sesuai dengan saran ahli materi, ahli desain dan ahli media.

Dapat disimpulkan bahwa aspek penilaian media dinyatakan "Sangat Layak" digunakan sebagai media pembelajaran Pendidikan Jasmani Olahraga, dan Kesehatan (PJOK) di SMK N 1 Sukalarang yaitu aspek pemakaian diperoleh hasil 4,6 atau $88 \%$.

\section{KESIMPULAN}

Kesimpulan dari penelitian ini berdasarkan hasil research and development Media Pembelajaran CD Interkatif terdapat beberapa hal:

1. Pengembangan Media Pembelajaran CD Interaktif dikembangkan melalui beberapa tahap yaitu (1) Potensi dan Masalah, (2) Pengumpulan Data, (3) Desain Produk, (4) Validasi Desain, (5) Revisi Desain, (6) Uji Coba Produk, (7) Revisi Produk, (8) Uji Coba Pemakaian / Lapangan, (9) Revisi Produk, dan (10) Produksi Masal. Dari beberapa langkah penilitian dan pengembangan yang dilakukan maka dapat disimpulkan bahwa peneliti menggunakan metode penelitian dan pengembangan hingga tahap ke-9 dikarenakan keterbatasana waktu dan biaya

2. Dari hasil pengembangan dihasilkan Media Pembelajaran CD Interaktif dengan skor rata-rata yang di diberikan oleh ahli materi yaitu 4,3 dengan kategori "Sangat Layak", ahli desain yaitu 4,3 dengan kategori "Sangat Layak", ahli media yaitu 3,5 dengan kategori "Layak", uji coba kelas terbatas oleh 6 siswa yaitu 4 dengan kategori "Layak" dan uji coba lapangan oleh 20 siswa yaitu 4,6 dengan kategori "Sangat Layak" sehingga Media Pembelajaran CD Interkatif dapat digunakan dalam pembelajaran Pendidikan Jasmani Olahraga, dan Kesehatan (PJOK).

3. Media Pembelajaran CD Interaktif dapat menjadi inovasi dalam mengembangkan media pembelajaran Pendidikan Jasmani Olahraga, dan Kesehatan (PJOK), hal ini dapat dilihat dari aspek-aspek penilaian siswa yang meliputi aspek motivasi belajar, kemudahan pemakaian, kemenarikan tampilan, dan kebermanfaatan.

4. Media Pembelajaran CD Interaktif merupakan media yang di sajikan lebih menarik, dilengkapi dengan visual, audio dan video disertai dengan animasi yang di buat menggunakan Software Adobe Flash CS5.5, media pembelajaran CD Interaktif diharapkan mampu membantu parasiswa memahami materi tentang senam lantai dalam proses pembelajaran di kelas maupun di luar kelas secara mandiri

\section{UCAPAN TERIMA KASIH}

Terima kasih saya ucapkan kepada universitas muhammadiyah sukabumi yang telah banyak memberikan saya ilmu selama 4 tahun ini, untuk dosen-dosen yang senantiasa membimbing dan memberikan arahannya untuk penyusunan jurnal ini. Terima kasih untuk SMK N 1 Sukalarang yang telah memberikan izin saya untuk pengambilan data dan meneliti tentang pendidikan di sana.

\section{DAFTAR PUSTAKA}

[1] Ambarjaya, B. S., Psikologi Pendidikan dan Pengajaran. Yogyakarta: CAPS, 2012.

[2] Peraturan Pemerintah No.29 Tahun 1990, Tentang Pendidikan Menenga Bab 1 Ayat 1 Pasal 3.

[3] Paramitha, S.T., \& Anggara, L.E, "Revitalisasi Pendidikan Jasmani untuk Anak Usia Dini melalui Penerapan Model Bermain Edukatif Berbasis Alam," Jurnal Pendidikan Jasmani dan Olahraga, pp. 41-51, 2018.

[4] Daryanto, Media Pembelajaran. Yogyakarta: Gava Media, 2013.

[5] Prastowo, A, Panduan Kreatif Membuat Bahan Ajar Inovatif. Yogyakarta: Diva Press, 2012.

[6] Sugiono, Metode Penelitian Pendidikan. Bandung: Alfabeta, 2018. 